\title{
THE EFFECTIVENESS OF ORGANIC FERTILIZATION IN IMPROVING THE PHYSICAL PROPERTIES OF SOIL
}

\author{
I Made Sukerta \\ University Mahasaraswati Denpasar, Bali, Indonesia \\ Ni Putu Eka Pratiwi \\ University Mahasaraswati Denpasar, Bali, Indonesia \\ Komang Dean Ananda \\ University Mahasaraswati Denpasar, Bali, Indonesia \\ DOI: 10.31364/SCIRJ/v9.i09.2021.P0921882 \\ http://dx.doi.org/10.31364/SCIRJ/v9.i09.2021.P0921882
}

\begin{abstract}
Low soil fertility and dry climate are factors that cause concern for farmers to cultivate mustard plants in the area. It is hoped that the improvement of the physical and chemical properties of the soil with the addition of nitrogen and vermicompost fertilizer will enable the successful cultivation of mustard plants in Nusa Lembongan. An experiment was carried out in the field in the dry land of Jungutbatu village, Nusa Lembongan, Klungkung, Bali, to study the effect of nitrogen dose and vermicompost on the growth and yield of mustard greens. The results of this experiment showed that the interaction between the dose of $N$ and vermicompost had a very significant effect on plant height at 21 and 28 DAP, leaf area index at 14, 21 and 35 DAP, fresh and oven-dried plant weight total ha-1. Treatment of $138 \mathrm{~kg} \mathrm{~N}$ ha' with $25 \mathrm{t}$ of vermicompost ha gave the highest total fresh and oven dry plant weight ha $\mathbf{( 2 3 8 . 5 2}$ and $12.53 \mathrm{t}$ ha-1, respectively). In this experiment, the optimum dose of $N$ and vermicompost was not obtained. The relationship between the dose of $N$ and vermicompost with the weight of fresh and oven-dried plants total ha was linear. The addition of $\mathrm{N}$ and vermicompost fertilizer increased leaf $\mathrm{N}$ content, levels of $\mathrm{C}$-organic and $\mathrm{N}$-total soil and improve soil physical properties. In this study, the optimum dose of both $N$ and vermicompost was not obtained. From the results of this study, it can be suggested to use a dose of $>138$ $\mathrm{kg} \mathrm{N}$ ha-1 with $>25 \mathrm{t}$ vermicompost ha-1 to obtain high green mustard yields on land with conditions similar to this experiment in the Nusa Lembongan area.
\end{abstract}

Keywords: Nitrogen, vermicompost, mustard greens

\section{INTRODUCTION}

In Indonesia, vegetable plants are included in the horticultural plant group which has an important role in everyday life. One type of vegetable in the trade is green mustard (Brassica juncea L.). Green mustard contains vitamins A, B, C, minerals and has advantages over other vegetable crops because it can be cultivated in both highlands and lowlands (Haryanto et al., 2006). Green mustard plants have been widely cultivated in the lowlands, especially in suburban areas by utilizing land around settlements whose irrigation has been interrupted and unused land in a narrow area. The ease of marketing, as well as the increasing needs encourage farmers to cultivate mustard greens all the time,

Efforts to develop vegetable crops have been carried out but are still not balanced with the increasing market demand. This situation is caused by the increasing population and awareness of public nutrition, as well as market demand for good quality with more diverse types.

The land in Jungutbatu Village, Nusa Lembongan, Klungkung Regency is dry land with low fertility and land productivity due to very low $\mathrm{N}$-total and $\mathrm{C}$-organic content (Appendix 1) with the limiting factor being water. The types of crops cultivated are generally corn and cassava. In this area the development of tourism is quite rapid, so the need for food, including vegetables, especially quality fresh green mustard is quite a lot, which has always been imported from Denpasar, so the quality of vegetables has decreased and in limited quantities. Meanwhile, farmers in Jungutbatu Village do not dare to take the risk of failure when cultivating mustard greens or other vegetables given the low soil fertility conditions and only depend on rainwater.

According to Subbhan and Wardjita (1984), there have been many improvements in plant cultivation techniques aimed at increasing the yield and quality of vegetables. One of them is by fertilization. Vaitu delivers nutrients into the soil to make them available to plants. Sarief (1986), said nitrogen is an important element needed by plants. Nitrogen is very helpful for plant growth, especially stems, branches, leaves and for the formation of proteins, fats and various other organic compounds (Prihmantoro et al, 2017). According to Lingga (2013), nitrogen plays a role in the formation of green leaves. Nitrogen deficiency causes the leaves to turn yellow and fall quickly. If nitrogen is excessive, plant growth becomes succulent and weak (Sutedjo, 2010).

Efforts to improve land conditions with low fertility can be done by providing organic fertilizers. Kascing fertilizer is one of the organic fertilizers that has advantages over other organic fertilizers, including having a faster effect and less use than other organic fertilizers. Kascing is earthworm droppings 
which is an excellent organic fertilizer. the nutrients contained in Jengkap, both macro and micro nutrients and can be directly available to plants. Cassworms have a low $\mathrm{C} / \mathrm{N}$ ratio both as a source of energy for microorganisms so that it will increase their effectiveness (Kartini, 199).

Based on the results of the study, the highest average yield of mustard greens per hectare was obtained at a dose of 90 $\mathrm{kg} \mathrm{N}$ ha-1 fertilization with a spacing of $20 \times 20 \mathrm{~cm}$, the total fresh weight yield was 47,157 tha (Panji, 1993). The results of the study of mustard greens on dry land in Patas Village, Gerokgak, Buleleng using a water volume of $1000 \mathrm{ml}$ day and $135 \mathrm{~kg} \mathrm{~N}$ ha-1, the total fresh weight yield and the highest total oven dry yield were $25.30 \mathrm{t}$ ha-1 and $258 \mathrm{t}$ ha-1 (Sadnyana, 2016). There is no farmer in Jungutbatu Village who cultivates mustard greens considering the condition of soil fertility is very low and only depends on rainwater, while research has never been carried out, there needs to be a solution so that farmers can meet the demand for fresh green mustard. Based on this, it is necessary to conduct research to examine the effect of nitrogen dose and vermicompost on the growth and yield of mustard greens (Brassica juncea L.) in the dry land of Jungutbatu Village, Nusa Lembongan. Based on the description above, research is carried out on the following problems:

1. Does the interaction between the dose of nitrogen and vermicompost affect the growth and yield of mustard greens?

2. What is the optimum dose of nitrogen and vermicompost in order to get the maximum yield of mustard greens?

\section{LITERATURE REVIEW}

\section{Green Mustard Plant Characteristics}

Mustard greens (Brassica juncea L.) belong to the Crucijerae family. Historically, mustard greens are thought to have originated from China (China) and East Asta, then spread to the Philippines and Taiwan (Haryanto et al., 2006). The entry of green mustard into Indonesian territory is thought to have been in the nineteenth century, along with the cross-trade of other types of sub-tropical vegetables, especially the cabbage group (Rukmana, 2004).

Mustard greens are annual plants with smooth, hairless leaves and no crop (Sunaryono, 2003). According to Rukmana (2004), the root system of mustard greens is a taproot and root branches that are elliptical in shape spreading in all directions at a depth of between $30-50 \mathrm{~cm}$, while the stem is very short and segmented so that it is almost invisible.

Mustard greens can grow both in the highlands and lowlands. A suitable planting area is at an altitude of 100 - $500 \mathrm{~m}$ above sea level. (Haryanto et al., 2006). Mustard greens want loose soil rich in organic matter with a $\mathrm{pH}$ of 67 (Nazaruddin, 2000). According to Rukmana (2004), several mustard varieties are resistant to heat, can grow and produce well in areas with temperatures between $27^{\circ} \mathrm{C}-31^{\circ} \mathrm{C}$.

This adult typeThe most widely sold mustard greens in the market are mustard greens. The petiole is long, slender, greenish-white. The leaves are wide, elongated, thin and green. It tastes crispy, fresh with a slightly bitter taste, making it much in demand. Besides being delicious, green mustard is much needed by traders of meatball noodles, chicken noodles, or Chinese cuisine restaurants so that the demand for it is very high every day (Haryanto et al, 2006). Mustard greens can be harvested at the age of 40-50 days, or the physical condition of the plant can be seen, that is, if the lower leaves have started to turn yellow, they will be harvested as soon as possible (Sugeng, 2008).

\section{Benefits of Kascing Organic Fertilizer}

According to Sarief (1986) what is meant by organic matter is the remains of plants and animals, especially those that have undergone an overhaul process such as manure, green manure, compost and others. Rosmarkam and Yowono (2015) added that organic matter will help reduce erosion, retain moisture, control $\mathrm{pH}$, improve drainage, reduce hardening and cracking and increase ion exchange capacity and soil biological activity.

The availability of nutrients for vegetable crops can also be met by giving organic fertilizers. Provision of organic fertilizer is useful for adding macro and micro nutrients, increasing water holding capacity, improving soil aeration and drainage, and preventing soil hardening in the event of drought (Sutedjo, 2010).

One type of organic fertilizer that has been circulating in the market is Kascing fertilizer, this fertilizer has advantages over other organic fertilizers so it is often called "organic fertilizer plus". Kascing is an excellent earthworm excrement. Because the nutrients it contains can be directly available to plants, it has a low $\mathrm{C} / \mathrm{N}$ ratio so that it is very bark as a source of energy for microorganisms to increase their activity. Giving vermicompost into the soil can improve the chemical and biological properties of the soil. Properties include improving soil structure, porosity, permeability, increasing the ability to withstand Chemical Properties including increasing soil ability to absorb cations as a source of macro and micro nutrients,

Mulat (2003), said that vermicompost contains complete nutrients (macro and micro elements), useful for plant growth. Kascing also contains many microbes, growthstimulating hormones (gibberellins, sitoldnin and auxin), humic acid and has a high CEC. The vermicompost is crumbly, this crumb structure can improve the weakness of clay which tends to saturate water quickly. Giving vermicompost can open locked spaces or pores, such as small tunnels, channeling water and air into the soil, forming a crumb structure. Kascing also has the ability to hold large amounts of water around 145-168\%, meaning it can increase water storage in the soil. Kascing is able to improve soil physical properties such as reducing soil weight, increasing soil porosity and permeability. High porosity facilitates root development,

\section{Research Hypothesis}

1. The interaction between the dose of $\mathrm{N}$ and the dose of vermicompost had a significant effect on the growth and yield of mustard greens.

2. The optimum dose of $\mathrm{N}$ and vermicompost was obtained for maximum yield of mustard greens. 


\section{RESEARCH METHODS}

\section{Location and Time}

The experiment was conducted in Jungutbatu Village, Nusa Lembongan, Klungkung, Bali from December 9, 2019 to January 30, 2020. The content of Ntotal, C-organic was very low at $0.09 \%, 0.55 \%$ respectively, while $\mathrm{P}$ and $\mathrm{K}$ - were available, medium (28.45 mg kg-1, 22.6 me 100g-1).

\section{Experimental design}

This experiment used a randomized block design (RAK) with two factors arranged in a factorial manner. The first factor is the dose of nitrogen which consists of 4 levels, namely:

1. $\mathrm{N} 0=0 \mathrm{~kg} \mathrm{~N}$ ha-1 ( $0 \mathrm{~kg}$ urea ha- $1 / 0 \mathrm{~g}$ urea plot- 1$)$

2. $\mathrm{N}_{1}=46 \mathrm{~kg} \mathrm{~N}$ ha-1 (100 kg urea ha-1/14.4 g urea plot-1)

3. $\mathrm{N}_{2}=92 \mathrm{~kg} \mathrm{~N}$ ha-1 (200 kg urea ha-1 / $28.8 \mathrm{~g}$ urea plot-1)

4. $\mathrm{N}_{3}=138 \mathrm{~kg} \mathrm{~N}$ ha-1 (300 kg urea ha-1 / $43.2 \mathrm{~g}$ urea plot-1) As the second factor is the dose of vermicompost fertilizer which consists of 6 levels, namely:

1. $\mathrm{K} 0=0 \mathrm{t}$ ha- 1 of vermicompost ( $0 \mathrm{~kg}$ of vermicompost- 1 )

2. $\mathrm{K} 1=5 \mathrm{t}$ ha- 1 of vermicompost $(0.72 \mathrm{~kg}$ of vermicompost1)

3. $\mathrm{K} 2=10 \mathrm{tha}-1$ of vermicompost $(1.44 \mathrm{~kg}$ of vermicompost 1 plot)

4. $\mathrm{K} 3=15 \mathrm{t}$ ha- 1 of vermicompost $(2.16 \mathrm{~kg}$ of vermicompost 1 plot)

5. K4=20 tha- 1 of vermicompost $(2.88 \mathrm{~kg}$ of vermicompost-1)

6. $\mathrm{K} 5=25 \mathrm{t}$ ha- 1 of vermicompost $(3.60 \mathrm{~kg}$ of vermicompost-1)

\section{Materials and tools}

The materials used in this experiment include: green mustard seeds of the Toksakan variety, urea fertilizer, vermicompost fertilizer, plastic bags, Baycarb insecticide and Derosal fungicide. The tools used in this experiment include: hoe, rope, stake, meter, hose, drum, bucket, gembor, knife, sprayer, ring pipe, ground drill, ruler, scale, oven and stationery.

\section{Data analysis}

The data collected were analyzed by analysis of variance (variance print) according to the design used. If there is a significant interaction effect on the observed variables, then proceed with Duncan's 5\% multiple distance test and if only a single factor influence, then treatment 5 is continued with $5 \%$ BNT test while treatment $>5$ is followed by Duncan's $5 \%$ multiple distance test. To determine the relationship between nitrogen dose and vermicompost on total fresh plant weight and total oven dry plant weight ha', regression analysis was performed (Gomez and Gomez, 1995).
Plants were slightly disturbed by locust pests, initially prevention was carried out by spraying Baycarp insecticide and Derosal fungicide once a week, then the intensity of spraying was increased to once every three days. Heavy rains at the end of crop growth (before harvest) caused some plants (outside the tiles) to be damaged (broken petioles), but this did not affect the overall crop yield. Mustard greens at the age of 14 and 28 DAP in the experimental plots are presented in.

The results of statistical analysis showed that the interaction between the dose of $\mathrm{N}$ and the dose of vermicompost had a very significant effect on plant height at 21 and 28 DAP, leaf area index at 14, 21 and 35 DAP, total fresh plant weight tan-1 and ha- 1 . The interaction of the two treatments also had a very significant effect on total oven-dry plant weight tan- 1 and ha- 1 , leaf $\mathrm{N}$ content, C-organic soil at harvest, soil moisture content at harvest, soil volume weight at 7 days old and at harvest., soil permeability at 7 DAP and harvest time, total soil pore space at 7 DAP and harvest. The dose of $\mathrm{N}$ had a very significant effect on all observed variables except Corganic soil at the age of 7 days after planting. The dose of vermicompost also had a very significant effect on all observed variables.

\section{RESEARCH RESULT}


Table 1

Significance of the effect of the application of doses of $N(N)$ and vermicompost $(K)$ and their interaction $(\mathrm{NxK})$ on the growth and yield variables of mustard greens

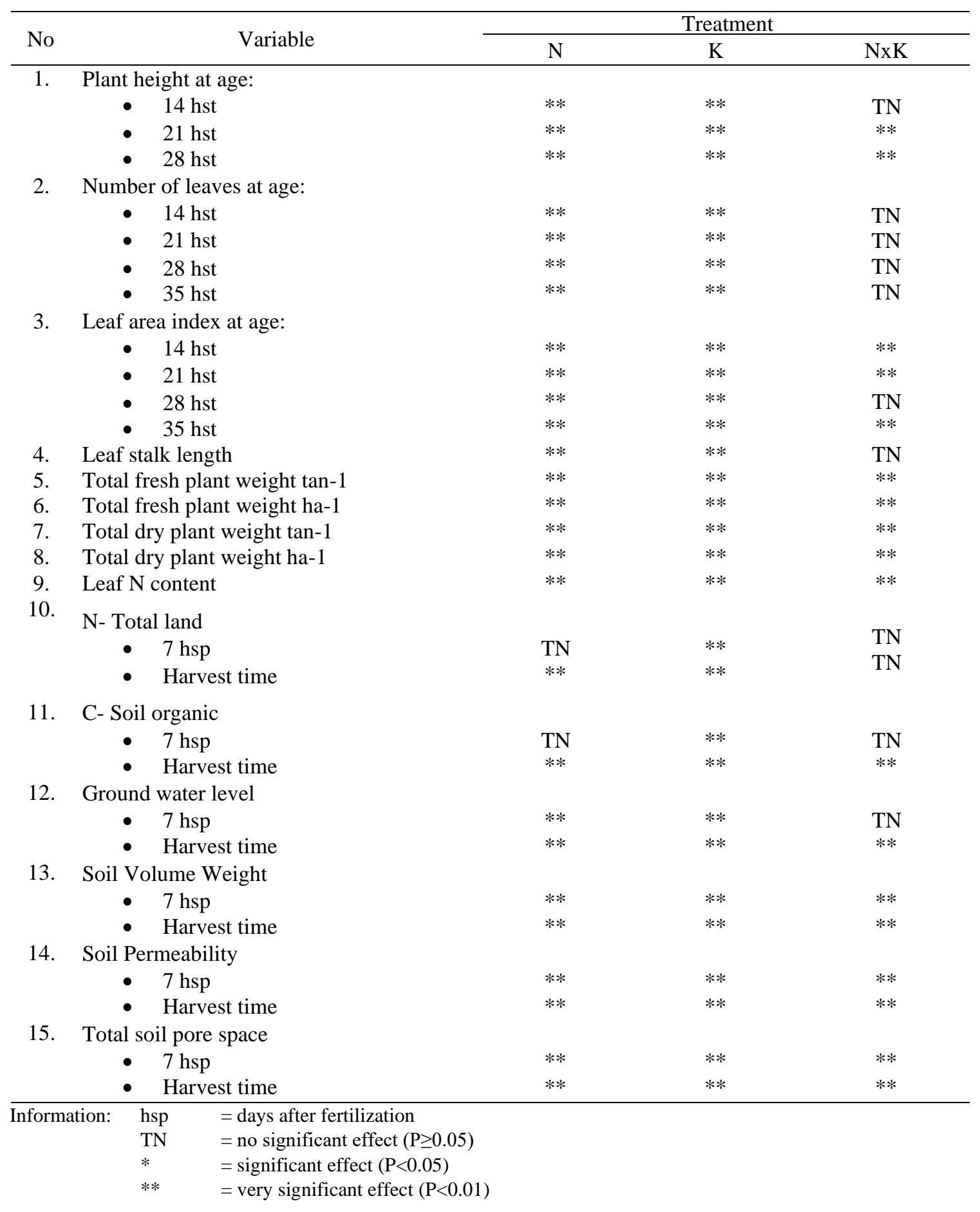




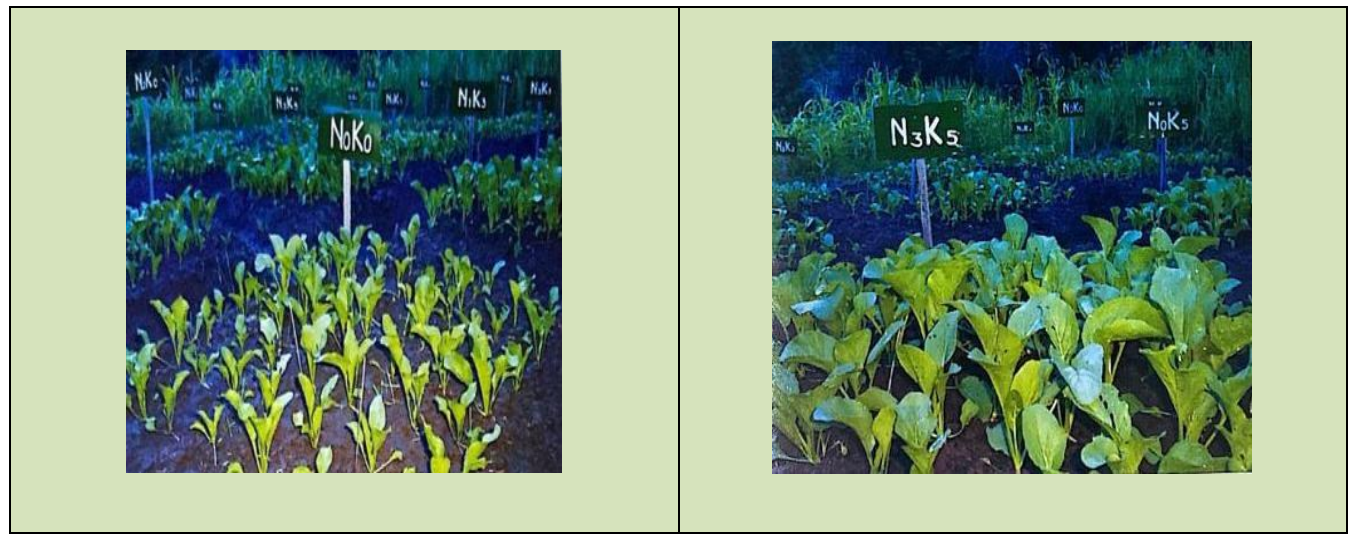

Figure 1

Mustard greens at the age of 14 days after planting.

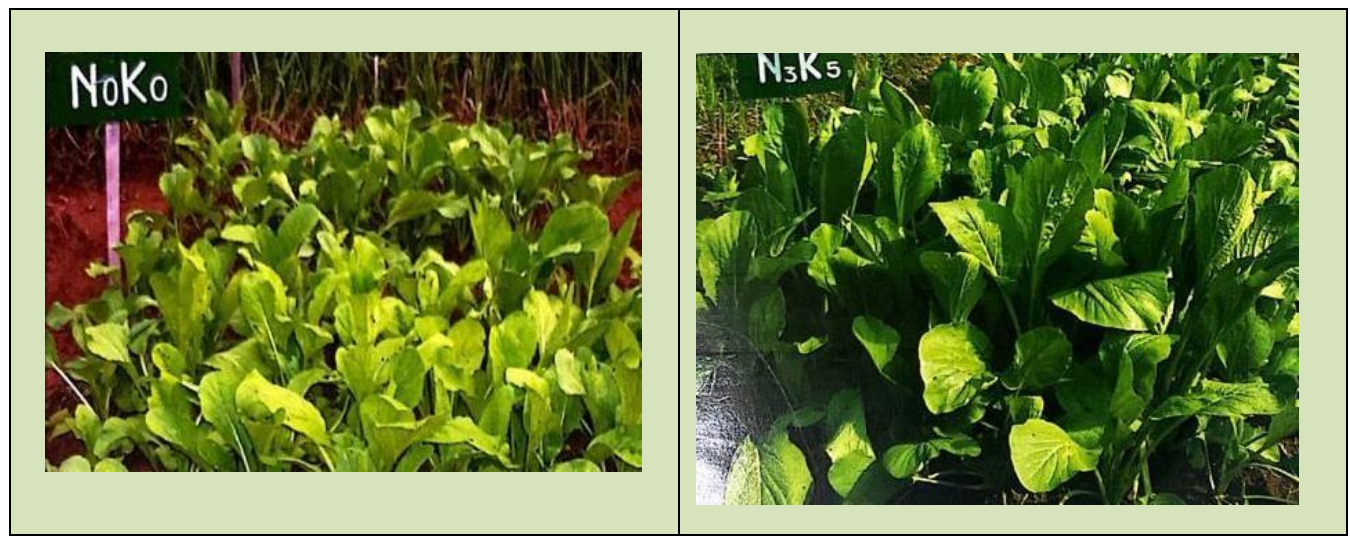

Figure 2

Mustard greens at 28 days after planting 


\section{Relationship between Dose of $N$ and Kascing Fertilizer with Fresh and Dry Weight of Plants Oven Total ha-1}

The relationship between the dose of vermicompost and total fresh plant weight ha-1 at each dose of $\mathrm{N}$ was linear with the respective regression equations: $\mathrm{Ysg}=64,124+2,287$ XNO: $\mathrm{R} 2=0991 ; \mathrm{r}=0995^{*} *$ Ysg $=95.821+2.725 \mathrm{XNI} ; \mathrm{R} 2=$ $0.965 ; \mathrm{r}=0.982 * * ; \mathrm{Ysg}=108,557+4,447 \mathrm{XN} 2 ; \mathrm{R} 2=0.985 ; \mathrm{r}$ $=0.992 * * ;$ Ysg; $=147,482+3,352 \mathrm{XN} 3 ; \mathrm{R} 2=0.976 ; \mathrm{r}=$ $0.988 * *$. The relationship between the dose of vermicompost and the total oven dry plant weight ha- 1 at each dose of $\mathrm{N}$ was also linear (Figure 5.6) with the respective regression equations: Yko $=3.716+0.115 \mathrm{XNO} ; \mathrm{R} 2=0.964 ; \mathrm{r}=0.983^{*} * ; \mathrm{Yko}=$ $4.801+0.115 \mathrm{XNI} ; \mathrm{R} 2=0.893 ; \mathrm{r}=0.945^{* *} ; \mathrm{Yko}=5067+$ $0.172 \mathrm{XN} 2 ; \mathrm{R} 2=0.940 ; \mathrm{r}=0.969^{*} *$ : Yko $=5.521+0.254 \mathrm{X}$; $\mathrm{R} 2=0.963 ; \mathrm{r}=0.981^{* *}$. The relationship between the dose of $\mathrm{N}$ and the total fresh plant weight ha-1 at each dose of vermicompost was linear (Figure 5.7) with the respective regression equations: Ysg $=63.195+0.606 \mathrm{Xko} ; \mathrm{R} 2=0.990 ; \mathrm{r}$ $=0.995^{* *} ; \mathrm{Ysg}=77.853+0.626 \mathrm{Xki} ; \mathrm{R} 20.977 ; \mathrm{r}=0.995^{* *}$; $\mathrm{Ysg}=91.806+0.638 \mathrm{Xk} 2 ; \mathrm{R} 2=0.992 ; \mathrm{r}=0.996^{* *} ; \mathrm{Ysg}=$ $100.074+0.722 \mathrm{Xk3} ; \mathrm{R} 2=0.989 ; \mathrm{r}=0977 * * ; \mathrm{Ysg}=112.188+$ $0.748 \mathrm{~K} 4 ; \mathrm{R} 2=0.980 ; \mathrm{r}=0.960 * * ; \mathrm{Ysg}=127.222+0.890 \mathrm{ks}$; $\mathrm{R} 2=0.950 ; \mathrm{r}=0.975^{* *}$. The relationship between the dose of $\mathrm{N}$ and the total oven dry plant weight ha-1 at each dose of vermicompost was also linear (Figure 5.8) with the respective regression equations: Yko $=3.765+0.01643 \mathrm{ko} ; \mathrm{R} 2=0.865 ; \mathrm{r}$ $=0.930 * * ; \mathrm{Yko}=4.66+0.01437 \mathrm{Xki} ; \mathrm{R} 2=0.975 ; \mathrm{r}=0.987 * *$; $\mathrm{Yko}=4.874+0.02259 \mathrm{XK} 2 ; \mathrm{R} 2=0.957 ; \mathrm{r}=0.978^{* *} ; \mathrm{Yko}=$ $5.228+0.02593 \mathrm{Xk} 3 ; \mathrm{R} 2=0.991 ; \mathrm{r}=0.991 ; \mathrm{r}=0.995^{* *}$. In this experiment, the dose of $\mathrm{N}$ and vermicompost fertilizer has not been obtained. The relationship between the dose of vermicompost and total fresh plant weight ha-1 at each dose $\mathrm{N}$ : Ysg = 64,124 + 2,287 XNo; R2 = 0.991; $\mathrm{r}=0.995^{* *} ; \mathrm{Ysg}=$ $95.821+2.725 \mathrm{Xn} 1 ; \mathrm{R} 2=0.965 ; \mathrm{r}=0.985 * * ; \mathrm{Ysg}=108,557+$ $4,447 \mathrm{XN} 2 ; \mathrm{R} 2=0.985 ; \mathrm{r}=0.992 * *, \mathrm{Ysg}=147.482+3.352$ $\mathrm{XN} 1 ; \mathrm{R} 2=20.976,+0.988^{*} *$. The relationship between the dose of vermicompost and the total weight of oven dry plants ha"! at each dose $\mathrm{N}:$ Yko $=3.716+0.115 \mathrm{XNo} ; \mathrm{R} 2=0.964: \mathrm{r}$ $=0.983 * * ; \mathrm{Yko}=4.801+0.115 \mathrm{X}_{\mathrm{NI}} ; \mathrm{R} 2=0.893 ; \mathrm{r}=0.94568, \mathrm{Yko}=$ $5.067+0.172 \mathrm{XN} 2 ; \mathrm{R} 2=0.940 ; \mathrm{r}=0.969^{* *} ; \mathrm{Yko}=5.521+0.254 \mathrm{Xn} 3 ; \mathrm{R} 2=$ $4.963 ; \mathrm{r}=0.981 * *$.

\section{DISCUSSION}

The interaction between the dose of $\mathrm{N}$ and vermicompost fertilizer had a very significant effect on the yield of mustard greens as evidenced by the interaction effect on the total fresh and oven-dry weight of plants ha-1. Increasing the dose of $\mathrm{N}$ at almost every increase in the dose of vermicompost resulted in an increase in plant weight (above soil) total oven dry ha-1. the highest value for this variable was $12.53 \mathrm{t}$ ha-1 produced by the treatment of $138 \mathrm{~kg} \mathrm{~N}$ ha-1 with $25 \mathrm{t}$ vermicompost ha-1. The increase in plant weight (above ground) oven-dry total ha-1 was due to an increase in total fresh plant weight ha-1 which also reached the highest value $(238.52$ t ha-1) due to the interaction effect of the two treatments. The yield of mustard greens obtained in this experiment was much higher than the results in the Sadnyana experiment (2016) in Patas Village, Grokgak, Buleleng Regency, namely $25.30 \mathrm{t}$ of fresh plants and $2.58 \mathrm{t}$ of oven-dried plants ha-1, respectively.
This may be caused by not using vermicompost fertilizer in Sadnyana's (2016) experiment even though the organic $\mathrm{C}$ was low, namely (1.26\%), although $\mathrm{N}$ was given as much as $135 \mathrm{~kg}$ $\mathrm{N}$ ha-, so that the physical condition of the soil was not as good as in the Nusa Lembongan experiment. Panji (1993) only obtained a fresh weight of green mustard plant of 47,157 tha-1 at a spacing of $20 \mathrm{~cm}$ x $20 \mathrm{~cm}$ with $90 \mathrm{~kg} \mathrm{~N}$ ha- 1 fertilization. The high value of the two variables (fresh and oven-dry total plant weight ha-) due to the interaction treatment was supported by the value of fresh plant weight and total oven-dry weight. The high yield of mustard greens both tan-1 and ha- 1 in the treatment of $138 \mathrm{~kg} \mathrm{~N}$ ha- 1 with $25 \mathrm{t}$ of vermicompost ha- 1 was very likely due to the high production of assimilate in the leaves. This was evidenced by the high leaf area index at the ages of 14, 21 and 35 DAP. The higher leaf area index was caused by the higher doses of $\mathrm{N}$ and vermicompost fertilizer so that it reached the highest values of 1,839, 3,330 and 13,393 at the age of 14.21 and 35 days after planting, respectively. The high leaf area index value was caused by the high leaf area value because it turned out that the number of leaves was not significantly affected by the interaction of the treatment dose of $\mathrm{N}$ and vermicompost. The wider leaves can receive and capture more solar radiation for the needs of the photosynthesis process in the leaves so that assimilate production becomes higher. Leaf area indexes of 1.06 and 3.43 were obtained by Sadnyana (2016) by fertilizing 135 $\mathrm{kg} \mathrm{N}$ ha- and giving $1000 \mathrm{ml}$ of water a day -1 ton- 1 , but without vermicompost, at the age of 21 DAP and 32 DAP, respectively.

The higher doses of $\mathrm{N}$ and vermicompost fertilizer resulted in better plant growth. This was evidenced by the highly significant effect of the interaction of the two treatments on plant height at the age of 21 DAP and 28 DAP. Plants reached a height of $6.45 \mathrm{~cm}$ at the age of 21 days after planting and increased to $10.34 \mathrm{~cm}$ at the age of 28 days with $138 \mathrm{kgN}$ ha of treatment with $25 \mathrm{t}$ of vermicompost ha-. The value of the variable height due to the plant may also cause the plant to become heavier and thus contribute to the variable value of the total plant weight.

The high growth and yield of mustard greens in this experiment was caused by high levels of organic $\mathrm{C}$ and $\mathrm{N}$-total soil. The treatment of $138 \mathrm{~kg} \mathrm{~N}$ ha- with $25 \mathrm{t}$ of vermicompost ha- 1 resulted in the highest organic $\mathrm{C}$ content $(1.67 \%)$ and the lowest value was given by the treatment without $\mathrm{N}$ and vermicompost $(0.40 \%)$ at harvest. The effect of the interaction between the dose of $\mathrm{N}$ and vermicompost was not significant at the age of 7 days after fertilization so that at that age only the dose of vermicompost had a single effect. The increase in the dose of vermicompost significantly increased the soil content so that it gave the highest value $(1.76 \%)$ at the age of 7 DAP, which was higher than without vermicompost.

The interaction effect of the two treatments was not significant on $\mathrm{N}$-total soil both at the age of $7 \mathrm{hsp}$ and at harvest but each treatment had a singular effect on nvata. Increasing the dose of $\mathrm{N}$ from 0 to $138 \mathrm{~kg} \mathrm{~N}$ ha- 1 significantly increased total soil $\mathrm{N}$ at both ages. The dose of vermicompost fertilizer which increased from 0 to 25 t ha- 1 also significantly increased the total soil $\mathrm{N}$-total at both ages. This shows that in addition to urea as a source of $\mathrm{N}$, vermicompost fertilizer can also release $\mathrm{N}$ after decomposition and mineralization in the soil (Buckman and Brady, 1982). This is because the vermicompost fertilizer contains high $\mathrm{N}$ (Appendix 2).

The contribution of $\mathrm{N}$ by vermicompost to the increase in total soil $\mathrm{N}$ may increase the $\mathrm{N}$ uptake by plants. This was 
evidenced by an increase in leaf $\mathrm{N}$ levels due to an increase in $\mathrm{N}$ dose at each increase in the dose of vermicompost. The highest leaf $\mathrm{N}$ content $(4.21 \%)$ was produced by the treatment of $92 \mathrm{~kg} \mathrm{~N}$ ha-1 at a dose of $25 \mathrm{t}$ of vermicompost ha- 1 which was not significantly different from that level at a treatment dose of $138 \mathrm{~kg} \mathrm{~N}$ ha at the same dose of vermicompost. Nitrogen is an essential macronutrient that plants need in large amounts. Nitrogen forms chlorophyll, protein, fat and various other organic compounds (Lingga, 2013). The more nitrogen in the leaves resulted in the amount of protein more so that the leaves grow wider (Hakim et al., 1986). In the experiment on Nusa Lembongan, It turned out that not only did the leaf area increase, but the leaf stalk of the mustard greens also increased due to the increased dose of $\mathrm{N}$ and vermicompost. The increase in leaf stalk length may also increase the fresh and oven-dried plant weights total tan-1 and ha1.

The application of organic fertilizers into the soil can improve the physical properties of the soil in addition to improving the chemical properties of the soil. The improvement in the physical properties of the soil was indicated by a decrease in the weight value of the soil volume and conversely an increase in the total pore space and soil permeability both at the age of 7 days after harvest and at harvest. Increasing the dose of vermicompost from 0 to $25 \mathrm{t}$ ha- 1 significantly reduced the soil volume in each treatment with a dose of $\mathrm{N}$ (Table 5.14). Mulat (2003) also reported that the application of vermicompost fertilizer at a dose of $40 \%$ was able to reduce the weight of the soil volume from 0.95 to $0.66 \mathrm{~g} \mathrm{~cm}-3$. In the experiment in Nusa Lembongan, the treatment of $138 \mathrm{~kg} \mathrm{~N}$ ha-1 with $25 \mathrm{t}$ of vermicompost ha- 1 gave the lowest soil volume weight value at the age of 7 days $(0,787 \mathrm{~g} \mathrm{~cm}-3)$ and at harvest the lowest value $\left(0.841 \mathrm{~g} \mathrm{~cm}^{\prime}\right)$ was also given by the treatment but was not significantly different from the value at the treatment dose of 25 $\mathrm{t}$ vermicompost ha- 1 without $\mathrm{N}$. This indicates that the soil becomes more friable due to the increase in organic matter in the soil resulting in an increase in the total soil pore space at the age of 7 DAP and at harvest. The highest value of this variable at each age ( $70.32 \%$ and $68.26 \%$ respectively) was given by the treatment of $138 \mathrm{~kg} \mathrm{~N}$ ha- 1 with $25 \mathrm{t}$ vermicompost ha- 1 . The results of this experiment are in accordance with the statement of Ismail and Utomo (2016) that the higher the soil organic matter, the lower the density, which allows plant roots to develop freely.

High organic matter content can increase soil humus, increasing the soil's ability to hold water. An increase in the dose of vermicompost at each dose of $\mathrm{N}$ resulted in an increase in soil water content at harvest. Meanwhile, at the age of $7 \mathrm{hsp}$, the dose of $\mathrm{N}$ and the dose of vermicompost fertilizer alone affected the soil moisture content. Increasing the dose of $\mathrm{N}$ from 0 to 138 $\mathrm{kg} \mathrm{N}$ ha-1 and increasing the dose of vermicompost from 0 to $25 \mathrm{t}$ of vermicompost ha-1 significantly increased soil moisture content. The results of Jatmiko's (1997) study also showed that the addition of manure up to $40 \mathrm{t}$ ha- 1 in addition to reducing the weight value of the soil volume and increasing soil porosity, also increased the ability to hold water and increased available ground water.

The relationship between the treatment of doses of $\mathrm{N}$ and vermicompost, respectively, with the fresh and oven-dry weight of the total plant ha which is linear indicates that the maximum yield has not been achieved and the optimum dose for both $\mathrm{N}$ and vermicompost has not been obtained in this experiment. Therefore, it is necessary to conduct further research to determine the optimum dose of each of these fertilizers to achieve maximum yields.

\section{CONCLUSIONS AND SUGGESTIONS}

\section{Conclusion}

The interaction between the dose of $\mathrm{N}$ and vermicompost had a very significant effect on plant height at 21 and 28 DAP, leaf area index at 14, 21 and 35 DAP, fresh and oven-dried plant weight total ha-1. The treatment of $138 \mathrm{~kg} \mathrm{~N}$ ha- 1 with $25 \mathrm{t}$ of vermicompost ha- 1 gave the highest total fresh and oven-dried plant weight ha-1 (238.52 and $12.53 \mathrm{t}$ ha-1, respectively). In this experiment, the optimum dose of $\mathrm{N}$ and vermicompost was not obtained. The relationship between the dose of vermicompost and the total weight of fresh and ovendried plants ha-1 at each dose of $\mathrm{N}$ was linear and vice versa. The addition of $\mathrm{N}$ and vermicompost increased the leaf $\mathrm{N}$ content, organic $\mathrm{C}$ content and total $\mathrm{N}$ content of the soil and improved the physical properties of the soil. The effect of $\mathrm{N}$ was very significant on all observed variables except for $\mathrm{C}$-organic content of soil aged 7 days after planting, while the effect of vermicompost fertilizer on all observed variables.

\section{Suggestion}

To obtain high green mustard yields on land with the same conditions as the experiment in the Nusa Lembongan area, doses equal to or greater than $138 \mathrm{~kg} \mathrm{~N}$ ha and $25 \mathrm{t}$ vermicompost ha1 can be used.

\section{REFERENCES}

[1] Buckman, HO, Brady, NC 1982. Soil Science. Soegiman translation. Jakarta: Bhratara Karya Aksara. 788 pg

[2] Gomez, KA, Gomez, AA 2007. Statistical Procedures For Agricultural Research. Translation of Sjamsuddin E. Raharsiah JS, Jakarta: University of Indonesia 698 p. 9004

[3] Hakim, N., Nyakpa, MY Lubis, A., Nugroho, SG, Saul, R., Pika, MA, Go Ban Hong, Bailey, HH 1986. Fundamentals of Soil Science. Lampung : University of Lampung. pp. 325-327.

[4] Harjadi, SS 2019. Introduction to Agronomy. Bandung : Gramedia.

[5] Haryanto, E., Suhartini, T., Rahayu, E. 2006. Mustard and Lettuce. Jakarta: Self-help spreader.

[6] Ismail, T., Utomo, WH 2016. Relationship of Soil, Water and Plants. Semarang: Teacher Training and Education Institute.

[7] Jatmiko, H. 1997. Application of Manure and Plastic Mulch on Sand Dune Regosol. Special Edition, Malang : Balitkabi (10): 187-193.

[8] Kartini, NL 1997. Effects of Vesicular-Arbuscular Mycorrhizal (MVA) and organic vermicompost on 
available P, Plant P content and Yield of Shallots (Allium sativum L.) in Inceptisols, (dissertation) Bandung Padjadjaran University.

[9] Lingga, P. 2013. Instructions for Use of Fertilizers. Jakarta: Self-help spreader.

[10] Mulat, T. 2003. Making and Utilizing Quality Organic Fertilizer Kascings. Third printing. Jakarta : Agro Media Library.

[11] Nazaruddin. 2000. Lowland Vegetables. Jakarta: Selfhelp spreader.

[12] Panji, WYG 1993. Effect of Plant Spacing and Nitrogen Dosage on Growth and Yield of Mustard Flower (Brassica juncea L) (thesis). Singaraja : Panji Sakti University.

[13] Prihmantoro, H., Indriani, HYH, Buhardi, S. 2017. Practical Instructions for Fertilizing Vegetable Crops. Jakarta: Self-help spreader.

[14] Rinsema. 1986. Fertilizer and Fertilization Method. Jakarta: Brata Karya Aksara.

[15] Rosmarkam, A., Yuwono, NW 2015. Soil Fertility Science. Yogyakarta : Kanisius.

[16] Rukmana, R. 2004. Planting Petsai and Mustard Greens. Yogyakarta : Kanisius

[17] Sadnyana, M. 2016. Effect of Volume of Water and Nitrogen Fertilizer Dosage on Yield of Mustard (Brassica juncea L) in Drip Irrigation System (Thesis). Denpasar : Udayana University.

[18] Sarief, ES 1986. Fertility and Fertilization of Agricultural Soil. Bandung : Pustaka Buana.

[19] Soepardi, G. 1997. Soil Properties and Characteristics. Bogor : Department of Soil Science, Faculty of Agriculture. Bogor Agricultural Institute.

[20] Subbhan, W. 1984. Effect of Utilization of Agricultural Waste on Tomato Production. Horticultural Research Results Report. Lembang : Horticultural Research Institute.

[21] Sugeng, HR 2008. Vegetable Farming. Semarang: Various Knowledge. Sunaryono, H. 2003. Key to Growing Vegetables - Important Vegetables in Indonesia. Jakarta: New Light.

[22] Suprapto, Adijaya, IN, Mahaputra, IK, Yasa, IMR 2000. Final Report on Farming Business System Research on Marginal Land Verification. Denpasar : Agricultural Technology Research and Assessment Agency.

[23] Sutedjo, MM 2010. Fertilizer and Fertilizer Method. Jakarta: Rineka Cipta. Suwarjo, 1992. Dry Land Management in Transmigration Areas. Business Proceedings

[24] Dry Land Farming. Jakarta : Ministry of Agriculture, Directorate General

[25] Food Crops, Directorate of Plant Expansion. Pages 12 16.

[26] Widiyazid, K. 1997. Pattern and Character of Urban Behavior Farming Business. Technology Application Paper.

[27] Winaya, PD 1983. Soil Fertility and Fertilization. training. Denpasar : Faculty of Agriculture, Udayana University. 
